New Series.-Vol. XIII., No. 2-issued November, 1924.

[Price Seven Shillings, net.]

\title{
Journal
}

OF THE

\section{MARINE BIOLOGICAL ASSOCIATION}

or

\section{THE UNITED KINGDOM.}

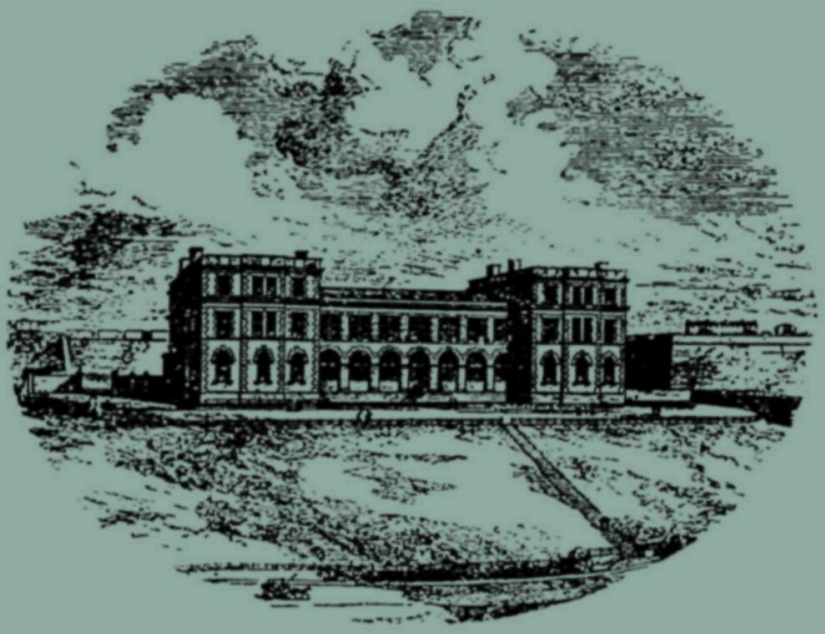

THE PLYMOUTH LABORATORY.

PLYMOUTH:

PRINTED FOR THE MARINE BIOLOGICAL ASSOCIATION AT THE MAYFLOWER PRESS BY W. BRENDON \& SON, LTD.,

AND

PUBLISHED BY THE ASSOCIATION AT ITS OFFICES ON THE CITADEL HILL. SENT FREE BY POST TO ALL MEMBERS OF THE MARINE H!OLOGICAL A8sOCIATION : ANXUAL SEBSCRIPTION FOR MEMBERSHIP, CXE GUINEA.

AGRYIB IN LONDON : YRSSKS, DULAU \& CO., LTD., 34-36, MAROARET STKEET, CAVKNDISH SQUARE, w. 1. 